\title{
A case study on argumentation based teaching
}

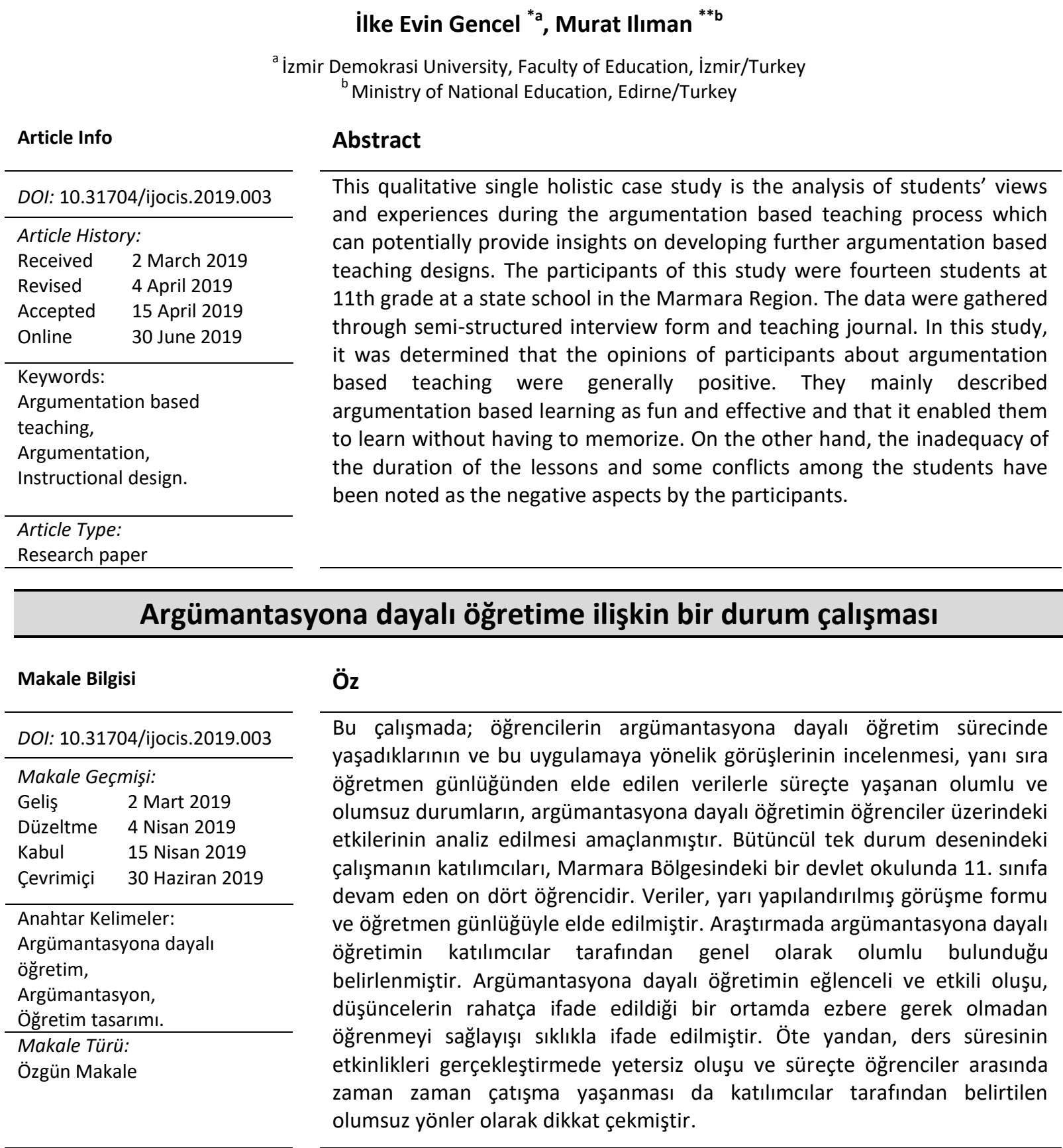

\footnotetext{
* Author: ilke.evingencel@idu.edu.tr

Author: ilmanmrt@hotmail.com
}

Orcid ID: https://orcid.org/0000-0002-2113-701X Orcid ID: https://orcid.org/0000-0001-5215-2987 


\section{Introduction}

With the development of constructivist theory of learning, the acquisition of the skills such as critical thinking, developing and supporting arguments, reasoning by learners has become one of the main purposes in education. In accordance with this theory, learners are expected to access to information sources, to question the accuracy of the information they receive, to express their opinions in a clear way, to perform a problemsolving process based on logical reasons and to discuss their opinions. As the main component of scientific thinking, argumentation, which incorporates a claim, a datum and a warrant, is deemed inseparable from this process (Kuhn, lordanaou, Pease \& Wirkala, 2008; Noroozi, Weinberger, Birmans, Mulder \& Chizari, 2012; Voss \& Van Dyke, 2001).

Argumentation is defined as a structured method of scientific discussion and traces back to as early as Aristotelian logic. In his works on arguments, Aristotle identified three groups as didactic, rhetoric and dialectic. Didactic arguments seek to present one point of view through inductive and deductive reasoning; rhetorical arguments are intended to convince one of the opinions expressed by a teacher or textbooks and dialectical arguments, which are relevant to the learner-centered approach, involve scientific discussions to justify a claim and to convince others (Andriessen, 2006; Jonassen \& Kim, 2010; Freelery \& Steinberg, 2013).

The model, which allows for the use of rhetorical and dialectical arguments in education, was proposed by Toulmin. Toulmin's model (1964) consists of claims, warrants between claims and evidences, backing for warrants, data, qualifiers as well as rebuttals indicating the situations where the claims are not valid. This model proposes that the acquisition of information from a single source of information such as teacher or textbook hinders individual development and creativity. Thus, the focus should be on arguments, not on information itself. Learners should lay arguments out and discuss the backings and rebuttals for these arguments with others (Fisher, 2004). In this information age, the acquisition of some skills is just as important as the acquisition of information; foremost among them are effective communication, questioning, collaboration, discussion, high-order thinking skills such as analysis, synthesis. Clearly, argumentation-based instructional designs present a model that can meet these needs. Indeed, Duschl and Osborne (2002) emphasized the importance of argumentation-based education in the acquisition of scientific ways of thinking by students. This process allows for an interaction environment that engages students to discuss on their claims both individually and collectively and to exchange information in a social and scientific platform for discussion (Burke, Greenbowe \& Hand, 2006; Choi, Hand \& Norton-Meier, 2014).

Toulmin (1964) states that reasoning is an effort that requires interaction to find a social meaning and suggests a scientific platform for discussion alternative to traditional reasoning. Discussion is not only about drawing conclusions from reasons it is also a process of learning about the facts through a kind of social contract, reshaped by backed and baseless claims. Toulmin's model emphasizes that discussion process depends on the context and that unlike traditional concepts of reasoning and discussion, there are no universally accepted standards. On the other hand, a generally unaccepted piece of information that is asserted as a claim can be recognized after being discussed through warrants, backings and rebuttals, and underlie another claim (Driver, Newton \& Osborne, 2000; Toulmin, 2001).

In argumentation-based discussion, a claim is a piece of information based on the data presented to others. Toulmin considers datum as a ground that incorporates evidence and reasoning. This discussion process also features the justified warrants supporting the claim based on data as well as the cases where the claim is not valid and rebutted. An example for this process is illustrated in Figure 1. This example explains argumentation based discussion reasonably clearly.

Harry was born
in Bermuda.
(Zemin/Datum) $\quad \begin{aligned} & \text { So/presumably/almost } \begin{array}{l}\text { certainly } \\ \text { (qualifier) }\end{array} \\ & \text { (Claim) }\end{aligned}$

\section{$\Uparrow$}

A man born in

Bermuda is $\Longleftarrow \quad$ Unless neither of his parents is generally a of British nationality, he has British subject. (Warrant) become an American. (Rebuttal)

Figure 1. Examples of argumentation-based discussion elements (Toulmin, 1964, 102). 
As seen in Figure 1, datum, claim and warrant form the basis of discussion. These elements are indispensable in an argumentation-based learning process. Other elements are considered additional elements that contribute to the soundness of the argument. Learning takes place in an interactive environment in the argumentation-based learning process. Thus, learners involved in the process improve both their higher-order cognitive skills and social skills through effective reasoning (Felton, 2005; Toulmin, 2001).

Toulmin's model of argumentation is regarded as a framework for students to acquire scientific thinking skills since scientific reasoning entails establishing relationships between arguments, analyzing options, thinking critically and proving (McNeil, Lizotte \& Krajck, 2006; Zohar \& Nemet, 2002). Indeed, it is reported that argumentation-based teaching enables one to understand science and scientific thinking (Bell \& Linn, 2000; Yerrick, 2000). Further, the process whereby the model is applied is associated with the concept of zone of proximal development coined by Vygotsky. To uncover the zone of proximal development, support from a more knowledgeable adult is necessary; studies show that the platform for discussion structured by the teacher in argumentation-based teaching is effective in providing such support (Simon, Erduran \& Osborne, 2006; Zohar, 2004).

Different activities can be developed for different curricula in the process of argumentation-based teaching; for instance, table of statements can be given to students and be asked to say whether they agree or disagree with them and argue for their choices; or the students can be asked to discuss arguments and form a concept map; or they can be presented with different theories in the form of cartoon/story and asked to state the one which they believe in and justify their decisions; or they can discuss arguments in groups of two or form two groups consisting of four members to discuss arguments; or listening trio where three students, one as the speaker, one as the questioner, and the other as the recorder, come together for a group discussion; envoy activity where there is a flow of information between groups about arguments and decisions made (Osborne, Erduran \& Simon, 2004). These activities can be implemented eclectically or separately.

Proved to bring many positive benefits to learners, argumentation-based teaching poses some challenges in practice. Among the most prominent challenges the difficulties that students face in bringing together subjects in different disciplines, and/or creating original ideas about the relevant subject through the help of media and other sources of information, the problems the introverted students experience in expressing themselves, the dominance of the students with weak arguments but capable of expressing themselves in a better way over those with strong arguments in a discussion that requires discussion skill (Kolsto, 2004; Bell \& Lederman, 2003). Further, the lack of a culture based on scientific discussion and argumentation in schools and the cultural and academic incapability of teachers to perform a type of teaching based on questioning and discussion are considered among potential challenges (Driver et al., 2001).

It is notable that argumentation-based teaching, suitable for constructivist teaching approach and encouraging versatile development, has been often studied in the field of science (Osborne, 2010); yet, it is applied in laboratory studies as well as nuclear power plant construction, genetically modified organisms, cloning, environmental awareness, illegal use of electricity much more (Tezel \& Yılmaz, 2017). Studies revealed that argumentation-based teaching has positive impact on university students' willingness to discuss (Baydaş, Yeşildağ Hasançebi \& Kilis, 2018), improves scientific process skills among learners (Duschl \& Osborne, 2002), increases their levels of conceptual understanding (Yerrick, 2000), enhances their capability of developing successful and valid arguments (Nussbaum \& Sinata, 2008; Venville \& Dawson, 2010), increases students' willingness to actively participate in the learning process (Kaya, Erduran \& Çetin, 2010; Martin \& Hand, 2009) and enhances students' achievement in science (Balcı \& Yenice, 2016; Cross \& Taasoobhirazi, 2008; Yeşildağ Hasançebi \& Günel, 2013; Yıldız \& Unal, 2016). It is also reported that argumentation-based teaching is seen as a positive practice by students as it increases learning opportunities (Kıngır, Geban \& Günel, 2011) and found effective in improving one's responsibility for learning and self-confidence (Kabataş \& Memiş, 2014). A major limitation of argumentation-based teaching is that it is time-consuming (Aktamış \& Atmaca, 2016; Simon \& Johnson, 2008). Argumentation-based teaching can be applied in various courses when properly adapted. Grbovic and Dragonic (2017) emphasized the necessity to perform learner-centered instruction in teaching geography, which is important for students to recognize, protect the environment they are in and to realize its potentials, and advised argumentation-based teaching.

Geography course is of importance for students since it entails, interdisciplinary subjects, including science, and requires understanding of complex and real-life relationships. Subjects such as climate change, natural disasters, food safety, nutrition, and urbanization and population problems are some of the subjects discussed through an interdisciplinary approach in the field of geography (Grobovicl \& Dragonic, 2017). The foremost reasons why geography is important is that it covers many important subjects such as sources related to the 
environment, also called the house of mankind, sustainable economic opportunities, ecosystem, climate, water resources, and that it enables learners to obtain information as well as to gain a world view. It is also significant that the skills such as spatial thinking, spatial analysis, holistic thinking, thinking about real-world problems, and awareness of one's individual and social identity are acquired in this process. To ensure the acquisition of these skills and characteristics, the focus should be on applying geography curriculum in a learner-centered way (Bonnett, 2008; Hicks, 2007; Maude, 2010). While the content of geography curriculum has a great potential to be used in argumentation-based teaching, the studies performed in Turkey and abroad are few. Among these studies, the study carried out by Grbovic and Dragonic (2017) is in descriptive review model and the level of student centered applications and using argumentation based teaching in geography course were revealed by applying a scale to the students. Nussbaum, Sinatra and Owens (2012) examined validity levels of argumentations produced by the students; Venville and Dawson (2010) examined the effect of argumentation based teaching on proving permanent learning; Torun and Şahin (2016) examined the effect of argumentation based teaching on decision and argument levels of students. As it is seen, the studies having been reached from the literature examines the argumentation based teaching application in some aspects. With this research designed as a case study, argumentation based teaching application is discussed with teacher and student's point of view; it contributes in points of difficulties and solution suggestions during applications. In this context the aim of research is analyzing experiences during argumentation based teaching with students and teacher point of view and prove data source for the periods of creating argumentation based teaching designs.

\section{Method}

\section{Research Design}

With the purpose of revealing the contribution of argumentation-based teaching to student learning and improvement, identifying the opinions of students on argumentation-based teaching and opinions teachers who make use of it in their implementations, this study employs a holistic single-case design (Yin, 2003) as a qualitative research methodology since it analyzes a single analysis unit with a holistic approach. The case examined is the Geography course in which argumentation based teaching was applied. Analysis unit is experiences and reactions in this course's teaching period. Limitations of the study are the application which was for four lessons and continued for four weeks and involving the subjects "Turkey: Center of Civilizations" and "Land Use in Turkey" in the unit "A Spatial Synthesis: Turkey". Table of statements, concept map, competing theories (cartoon/story), guess-watch-explain, couple conversation, couples to fours, listening trio, envoys, role play activities which are basic activities to carry argumentation based teaching out were held during the application.

\section{Participants}

The study uses convenience sampling, which is one of the purposive sampling methods. Following convenience sampling method, the researcher identifies and analyzes a case convenient for study (Wildemuth, 2009). The participants of the study are 14 students ( 11 female, 3 male) studying in 11th grade at a public high school in the region of Marmara, Turkey. The higher proportion of female students relative to male students may be considered as a limitation of this study.

\section{Data Collection Tools and Gathering Data}

It is important to gather the data from multiple resources in case studies, as in other qualitative research methods (Yin, 2003). To achieve data triangulation, semi-structured interviews were performed with the students and the teachers were asked to keep unstructured diaries of their reflections during the practice. A literature review was carried out and two faculty members specialized in the field of education programs and teaching were consulted to prepare the interview form. The form consists of five questions aimed at determining the opinions of the students about argumentation-based teaching. The interviews lasted for 25 to 30 minutes and were audio-recorded. They were transcribed by the researchers and the participants were asked to review the transcriptions.

Teacher diaries were also used to collect data for the study. The teachers of geography, which participated in the practice, were given 10-hour training before the practice. The training covers argumentation-based teaching, sample practices, table of statement, concept map, competing theories with cartoons and stories, 
İlke Evin Gencel, Murat Ilıman - Uluslararası Eğitim Programları ve Öğretim Çalışmaları Dergisi, 9(1), 2019, 53-72

predict-observe-explain, couple conversation, activity for four, listening trio, envoy activity, role-playing as well as other issues to be considered in the process. The teacher who instructed the practice has a master's degree. The practice lasted for four weeks and involved four course hours per week of instruction on the subjects of "Turkey, Center of Civilizations" and "Land Use in Turkey" in the section of "A Spatial Synthesis: Turkey." Throughout the process, the teachers were asked to record the challenges they encountered, the strengths of the practice as well as other things they experienced in the classroom in their diaries.

\section{Data Analysis}

The study performed coding-based, inductive content analysis and interpreted the data obtained from the interviews with the students and the teachers' diaries in a holistic way. The correspondence between the coders (Miles \& Huberman, 1994) was calculated as 81 percent by the researchers.

\section{Validity and Reliability}

In this study, the agreement on the coders is $81 \%$, which shows internal consistency; all audio records to describe the process in detail are stored and the notes on the transcribed forms regarding the coders are available for further review, which ensure confirmability; participant consent is given and the participants' own words are included using direct quotations, which indicate reliability; the process whereby the study is performed, its design, participants, data collection and analysis processes are described in detail, which is an indicator of transferability.

Labels: The opinions of the students are labelled as S1, S2, and so on.

\section{Results}

In the research, the transcriptions formed at the end of student interviews and teacher diaries were examined, the themes were formed by examining data obtained both data sources holistically. Accordingly, the themes: Contributions of Argumentation to the Teaching Period, Limitations in the Period of Argumentation Based Teaching, and Suggestions were formed. Examples of student opinions and statements in teacher diary related to the codes forming themes were presented without any changes.

\section{Findings Related to Contributions of Argumentation to the Teaching Period}

The codes forming this theme were enjoyable, permanent learning, imagination, self-confidence, involvement, friendship, critical thinking.

In the interviews, the students expressed that they often enjoyed during the process of argumentationbased teaching. For instance, S1 stated: "...I am a person who likes doing such activities at school. As I am also in the school's debate team, it was very nice. The courses were so enjoyable..." and $\mathrm{S} 5$ stated: "...I could say that I did not get bored while learning ...", and thus they emphasize the enjoyable nature of the courses. Indeed, the diaries reported that "...I witness that the students learn by having fun...", "...the students are actively engaged and have fun at the same time..." That is, the opinions of the teachers and the students are consistent and demonstrate that the practice was enjoyable.

The participants also agreed on another theme, which is permanent learning. 58 expressed that: "... in this way, we were able to express our own opinions and defend ourselves against different views. What we learnt became permanent because we discussed, talked about them a lot..." and S3 stated: "... it was very fruitful, since, in my opinion, it was catchier. Nobody kept their thoughts and we compensated for each other when we fell short..." S11 reported: "... I had more say than I did in other classes, was more involved in the course, learnt better. I won't forget it..." It is notable that there are several statements regarding this theme in the diaries: "... Particularly, today, in the activity of let's build your own civilization, are you in or out? it was impressive that the students explained the causes and results of their arguments and tried to refute the views of each other. Their active involvement in the activity, the exchange of ideas, the necessity to defend one's own ideas ensure that permanent learning takes place...", "... I will definitely mention this method to the teacher of history Mrs. S. and the teacher of Turkish Philology Mrs. D. It is necessary to ensure permanent learning..."

The participants often reported that argumentation-based teaching improves imagination. S6 stated: “... rather than listening a 40-minute lecture, we pondered on, learnt something and imagined the results. I did not 
know that I could imagine to that extent..." and the diaries included the following statements: "... they learn to approach from different perspectives and their imagination now surprises me..."

Another remarkable theme is self-confidence. S2 reflected that: “... We learnt more by listening to our peers while talking about the things we could not think of on our own. I do not like talking too much, but I had to put forward my opinions as the course involves discussion and I gradually became more and more confident..." and S14 stated: "... in time one gains the confidence to speak in front of a crowd..." It is further reported that argumentation-based teaching has positive impact on friendship relations. S9 said: “... you may be assigned to the group to which a person you do not like is assigned. You may see something good about his/her or realize that he/she is not that bad. This is a good thing..." and S10 stated: "... the classroom turns into a sharing place; you become friends with those you did not before..." One of the statements in the diaries is as follows: "... The exchange of opinions teaches them to respect others' opinions. I realize that their friendship develops into much more."

Both the teachers and the students mentioned that their critical thinking skills are improved. S4 stated: “... It is a good method, since I think it enables every student to express their opinions and to think freely; because, in a typical course, the teacher gives the information verbally but this method presents a freedom of thought and critical environment for each and every student..." and S7 reported: "... it is necessary to have a broad perspective. We sometimes criticize the opinions of our friends and disagree with them without hurting them..." S10 reflected: "... I believe that geography is mainly based on memorization. When information is memorized, it is forgotten after the exam. But, in argumentation method, we have a critical look and learn about each other's' ideas. The classroom turns into a sharing place..." The diaries included the following statements: "... In the activity of 'Paddy Fields Substantially Damaged', they could think critically by assuming the roles of prosecutorjudge and lawyer and even though they did not embrace the idea they had to defend, they tried to see it in a new light..." These statements are consistent with the opinions of the students.

\section{Findings Related to Limitations in the Period of Argumentation Based Teaching}

This theme was formed with the codes conflict, the need for the teacher to lecture, time-consuming. As the negative aspects of the practice, the participants mentioned that there was, occasionally, conflict in the classroom, that they needed the teacher to lecture and the activities were time-consuming and sometimes the course was not long enough to complete the activities. S1 stated: "... this way of teaching does not cause individual challenges, but disagreements may sometimes occur within the group. Because all of us have different opinions. For example, I do things by my own hook unlike my friends, so I can have difficulty in being in a group work..." S9 expressed: "... well, let me put it this way, sometimes a dispute arises..." The relevant statement in the diaries is as follows: "... there are some students who do not tolerate criticism. Today, when the opinion of A was not favored, A got angry and had a row...", which manifests that there were conflicts in the classroom. The students also mentioned that they needed the teacher to lecture more. Indeed, S6 stated: "the teacher explained only a few things and it was not sufficient in my opinion..." and S13 said: “... we tried to do something on our own after listening only a 5-minute lecture. I think the lecture should be longer. Another course is needed for that, but..." Further, commenting on the lack of time, $\mathbf{5 8}$ reflected: "... also, the course is not long enough. Well, we arrive, get ready for the course, ponder on the subject and put forward our ideas, time passes and just then, the class is over. Also, because of the break times, this became troublesome..." and S12 stated: "... if the course lasted longer, there might be different ideas put forward. Or, we would have more time to use more sources and then perform better presentations to defend our ideas..." and S13 said: "... it takes time. That is, the subjects are discussed rather than lectured, and this takes more time..." With regard to the lack of time, the following statements are excerpted from the diaries: "The activities take a long time. When I saw that the time allocated for discussion was not long enough, for a moment I thought that we could continue to discuss on WhatsApp or make video conference... We can form a group on Facebook and share the information and documents about the topics of the discussion so we can optimize time..." These statements are also taken into consideration in the theme of recommendations.

\section{Findings Related to Suggestion Theme}

The participants suggested some recommendations to make the practice more efficient. As mentioned above, the use of technology for a more efficient use of time was mentioned in the teacher diaries, which also presented the following recommendation: "... I will make use of music and videos more often during small group discussions. We need to create a positive atmosphere because the students can be tense while discussing 
suggestions..." In relation to this theme, S2 reflected: "... visual materials may be employed more frequently. Perform a play or play music. In this way, the practice can be improved..." and S6 stated: "... if this practice is performed in a more technological environment, which is equipped with computers and internet, we can find evidence about our own ideas and the ideas we defend. Or we can video chat with someone and get information from him or her..." S7 said: "...well, we can share something we saw on the social media to support our claim; that is, we can refer to the situation by saying that such thing happened before. I mean to support it with the examples..." and S11 mentioned: "...for example, we can bring our tablets to the school. I do not know how to say... Each group can exchange information..."

\section{Discussion, Conclusion and Implications}

This study concluded that the students, in general, hold a positive view towards the use of argumentationbased teaching in geography curriculum and that there are similar statements in the diaries of the teachers, who performed the teaching practice.

The participants stated that they enjoyed being actively involved in argumentation-based teaching and permanently learned the content in this process. The studies by Kaya, Erduran and Çetin (2010) as well as by Martin and Hand (2009) similarly revealed that the participants enjoyed their active involvement in the process. Likewise, Aktamış and Atmaca (2016), and Kabatas and Memiş (2014) highlighted that argumentationbased teaching is effective in ensuring permanent learning. Venville and Dawson also reported that discussing the content allows for permanent learning. In this sense, it can be argued that argumentation-based learning plays a key role in educational practices in the context of constructivist approach as well as active learning.

Argumentation-based scientific discussion between peers allows for a better understanding of the concepts in an active process (Canpos, Silva, Tecpan \& Zacla, 2016). It is suggested that tasks such as work sheets, writing and listing to enhance the effectiveness of this process should be made use of during the teaching-learning process (Keys, Hand, Prain \& Collins, 1999). The participants in this study were successfully carrying out the activities which can be perceived as an indicator of permanent learning.

The participants stated that argumentation-based teaching improves critical thinking skills. Learners, in argumentation-based teaching, need to employ their high-order thinking skills such as critical and reflective thinking. Indeed, Andrews (2015), Duschl and Osborne (2002), Glassner and Schwarz (2007), Lazarou, (2010) yielded consistent results. Given that curricula at each level highlight the importance of the development of critical thinking skills, argumentation-based teaching activities should be incorporated into the design of teaching processes. This should be the case for the curricula aimed at training teachers and the skills required to perform argumentation-based teaching should be included to pre-service and in-service teacher trainings.

In this study, argumentation-based teaching is found to be effective in enrichment of points of view and imagination just as in the study of Aktamış and Atmaca (2016). The students realized that they improved these aspects, which are considered to be significant in terms of constructivist learning approach and social learning, during the process of argumentation-based teaching; this is important not only for the curricula followed but also for the personal development of the students. Moreover, this finding seems to be consistent with the findings of Bean (1996), Chen and She (2012) as well as King (200), who reported that argumentation-based teaching enables students to ponder on evidence, to identify conflicting ideas, to think over alternative ideas, and to approach the situations from different perspectives.

Overall, both the teachers who performed the practice and the students emphasized the positive aspects; on the other hand, they also pointed to the lack of time for the activities and the conflicts between the students. There are studies in the literature, which reported the time-consuming nature of the activities (Aktamış \& Atmaca, 2016; Simon \& Johnson, 2008; Torun \& Sahin, 2016). Effective time management and detailed planning are prerequisite to resolve this limitation of the practice. Also, argumentation-based can be performed after the challenges to be addressed are grouped under sub-categories. Further, discussions initiated at the classroom, can be moved to online platforms with the help of technology through various means such as social media. The problem regarding the lack of time can be diminished once argumentationbased teaching is widely used in different curricula. The uncommon use of argumentation-based teaching may emerge as a factor in the problem regarding the lack of time. The more often students experience this practice, the more competent they will be in developing arguments and counter-arguments. In this way, time management problems can be resolved. Indeed, Torun and Sahin (2016) reported that the argumentation skills of the students improved over time in the course of social sciences and Crowell and Kuhn (2012) argued that argumentation is a skill that gradually improves. 
Although the students listed many advantages of argumentation-based teaching, they also expressed that they needed the teacher to lecture. This finding once again reminds that teaching styles and different learning preferences should not be disregarded. The use of a single method or practice in teaching may prevent some students from benefiting the process in an effective way. In this regard, argumentation-based teaching should be performed in company with different methods and techniques. Other forms of argumentation-based teaching can be designed in accordance with experiential learning cycle, which allows for planning a course where different learning styles and preferences can be taken into consideration. Accordingly, scientific studies would be required to analyze the effectiveness of argumentation-based teaching designed with these different methods, techniques and models.

This study ascertains that the practice of argumentation-based teaching at the course of geography is favored by both the students and the teachers engaged in the practice. Besides, studies on the effectiveness of argumentation-based teaching and on the weaknesses and strengths of this practice in the courses such as geography, history and social sciences in the literature is fairly limited to the best knowledge of the researchers of this study.. Thus, to fill the gap in the literature, further studies in the field of social sciences may focus on argumentation-based teaching, which has been examined in terms of a variety of different variables in the field of science. Furthermore, when it is considered that there were some conflicts stated by both students and teacher during this period, it is thought that training of conflict solution strategies and peer mediation must be given. Participants stated that time was insufficient during application. Time management strategies training can contribute to solve this problem encountered in the applications of argumentation based teaching. Experimental studies which examines the effects of argumentation based teaching on cognitive, affective and psychomotor learnings, and qualitative studies examining these periods will contribute the knowledge accumulation in the literature.

\section{Acknowledgement}

Some parts of this study were presented as verbal notice in the 5th International Curriculum and Instruction Congress. 


\section{TÜRKÇE SÜRÜM}

\section{Giriş}

Yapılandırmacı eğitim anlayışıyla birlikte, öğrenenlere eleştirel düşünme, argüman geliştirme ve geliştirdiği argümanları savunma, mantıksal akıl yürütme gibi becerilerin kazandırıması, eğitimin başlıca amaçları arasında yer almıştır. Bu anlayışa uygun olarak öğrenenlerden, bilgi kaynaklarına ulaşması, ulaşılan bilgilerin doğruluğunu sorgulaması, görüşlerini net biçimde açıklayabilmesi, sorun çözme sürecine mantıksal gerekçelerle yaklaşması ve düşüncelerini tartışması beklenmektedir. Iddia, veri, dayanak gibi bileşenlerden oluşan ve bilimsel düşünmenin temel bileşeni olarak görülen argümantasyon, bu sürecin ayrılmaz parçası olarak kabul edilmektedir (Kuhn, lordanaou, Pease \& Wirkala, 2008; Noroozi, Weinberger, Birmans, Mulder \& Chizari, 2012; Voss \& Van Dyke, 2001).

Argümantasyon; yapılandırılmış, bilimsel tartışma tekniği olarak ifade edilmekte ve temelleri Aristo'nun mantık alanındaki çalışmalarına dayanmaktadır. Aristo, çalışmalarında argümanları, didaktik, retorik ve diyalektik olmak üzere üç grupta ele almıştır. Didaktik argümanlarda; tümevarım ve tümdengelim akıl yürütme ile genellikle tek bir sonuca ulaşma, retorik argümanlarda daha çok öğretmen veya ders kitapları tarafından ortaya konan düşüncelerle ikna etme, öğrenen merkezli eğitim anlayışına uygun olan diyalektik argümanlarda ise ortaya atılan iddiayı kanıtlarla dayanaklandırma ve diğerlerini ikna etmeye yönelik bilimsel tartışmalar söz konusudur (Andriessen, 2006; Freelery \& Steinberg, 2013; Jonassen \& Kim, 2010).

Retorik ve diyalektik argümanların eğitim sürecinde uygulanmasına yönelik model, Toulmin tarafından ortaya konmuştur. Toulmin'in (1964) modeli; iddialar, kanıtlar ve iddialar arasındaki gerekçeler, gerekçeleri güçlendiren destekler, bilgiler, sınırlayıcılar ve iddiaların geçersiz olduğu durumları ortaya koyan çürütmelerden oluşmaktadır. Bu modelde öne sürülen görüş; öğretmen ve kitap gibi tek bilgi kaynağından bilgi edinilmesinin bireysel gelişimi ve yaratıcılığı engellediğidir. Bu nedenle odaklanılması gereken, bilgi değil argümanlardır. Öğrenenler argüman oluşturup bunları destekleyen ve çürüten durumlar hakkında düşüncelerini diğerleriyle tartışmalıdır (Fisher, 2004). Bilgi çağında, en az bilgiye sahip olmak kadar önemli olan becerilerin başında; etkili iletişim kurma, sorgulama, iş birliği yapma, tartışma, analiz, sentez gibi üst düzey düşünme gelmektedir. Argümantasyona dayalı öğretim tasarımlarının söz konusu gereksinimlere cevap verebilen bir model olduğu açıktır. Nitekim Duschl ve Osborne (2002) da öğrencilere bilimsel düşünme yollarını kazandırmada argümantasyona dayalı eğitimin önemini ifade etmektedir. Süreçte etkileşim ortamı oluşmakta, öğrencilerin iddialar üzerinde bireysel ve birlikte düşünmeleri gerçekleşmekte, sosyal ve bilimsel bir tartışma ortamında bilgiler paylaşılmaktadır (Burke, Greenbowe \& Hand, 2006; Choi, Hand \& Norton-Meier, 2014).

Toulmin (1964)'e göre akıl yürütme; etkileşim gerektiren sosyal bir anlam oluşturma çabasıdır. Bu düşünceden hareketle, geleneksel mantık yerine alternatif bir bilimsel tartışma ortamı önermektedir. Tartışma, sadece nedenlerden sonuç çıkarmak değildir. Desteklenen ve desteklenmeyen iddialarla yeniden şekillenen, gerçeklere bir anlamda sosyal bir anlaşma yoluyla ulaşılan bir süreçtir. Toulmin'in modelinde tartışma sürecinin bağlama göre farklılaştığı, klasik akıl yürütme ve tartışmadan farklı olarak, evrensel standartların bulunmadığı ortaya konmaktadır. Öte yandan, genel kabul görmemiş bir bilgi, iddia olarak ortaya atılıp gerekçe, destekleyici ve çürütücü kanıtlarla tartışıldıktan sonra kabul gören bir bilgiye dönüştükten sonra bir başka iddianın temelini oluşturabilmektedir (Driver, Newton \& Osborne, 2000; Toulmin, 2001).

Argümantasyona dayalı tartışmada, iddia; diğerlerinin görüşüne sunulan veriye dayalı bilgidir. Toulmin (1964) veriyi, kanıt ve akıl yürütmeyi kapsayan bir zemin olarak ele almaktadır. Tartışma sürecinde verilere dayalı iddiayı destekleyen haklı nedenler ve iddianın geçerli olmadığı, iddiayı çürütücü durumlar da ele alınmaktadır. Bu süreç Şekil 1'deki örnekle açıklanmaktadır. Bu örnek, argümantasyona dayalı tartışmayı oldukça anlaşılır biçimde açıklamaktadır.

Harry

Bermuda'da

Öyleyse/belki/kesin Harry İngiliz'dir

doğmuştur.

(niteleyici)

(Iddia)

(Zemin/Veri)

Çünkü genellikle Bermuda'da doğanlar İngiliz'dir

Eğer anne ve babası yabancı değilse

(Gerekçe)

Öyleyse Amerikalı olur.

(Çürütücü)

Şekil 1. Argümantasyona dayalı tartışma öğeleri örneği (Toulmin, 1964, 102). 
Şekil 1'de görülen veri, iddia ve gerekçe tartışmanın temelini oluşturmaktadır. Bu öğeler, argümantasyona dayalı öğretim sürecinde mutlaka bulunmalıdır. Diğer öğeler, tartışmanın geçerliliğine katkı sağlayan yardımcılar olarak görülmektedir. Argümantasyona dayalı öğretim sürecinde öğrenme, bir etkileşim ortamında gerçekleşmektedir. Böylelikle öğrenenler sürecin bir parçası olarak, etkin biçimde akıl yürütme yoluyla hem üst düzey bilişsel becerilerini hem sosyal becerilerini geliştirmektedir (Felton, 2005; Toulmin, 2001).

Toulmin'in argümantasyon modeli, öğrencilere bilimsel düşünme becerisini kazandırmada bir çatı olarak değerlendirilmektedir. Çünkü bilimsel akıl yürütmede, argümanlar arasında ilişki kurma, seçenekleri analiz etme, eleştirel düşünme ve kanıtlama gerektirmektedir (McNeil, Lizotte \& Krajck, 2006; Zohar \& Nemet, 2002). Nitekim argümantasyona dayalı öğretimin bilimi ve bilimsel düşünmeyi anlamayı sağladığı ifade edilmektedir (Bell \& Linn, 2000; Yerrick, 2000). Ayrıca modelin uygulanma süreci, Vygotsky'nin yakınsal (potansiyel) gelişim alanı terimi ile de ilişkilendirilmektedir. Potansiyel gelişim alanının ortaya çıkması için daha bilgili bir yetişkinin desteği gereklidir ki argümantasyona dayalı öğretimde öğretmen tarafından yapılandırılan tartışma ortamının bu işlevi yerine getirmede etkili olduğunu ifade eden çalışmalar bulunmaktadır (Simon, Erduran \& Osborne, 2006; Zohar, 2004).

Argümantasyona dayalı öğretim sürecinde farklı öğretim programları için farklı etkinlikler geliştirilebilir. Örneğin ifadeler tablosu etkinliği; öğrencilerin kendilerine verilen ifadelere katılma durumlarını argümanlarıyla birlikte açıklamasını, kavram haritası etkinliği; argümanların tartışılarak kavram haritası oluşturmasını, karikatürlerle/hikayelerle yarışan teoriler etkinliği; adından da anlaşılacağı üzere karikatür/hikaye olarak sunulan farklı teorilerden hangisinin seçildiğini gerekçelendirmesini, çift konuşması etkinliği; argümanlar üzerinde ikililer olarak tartışılmasını, çiftler dörtlere etkinliği; ikili grupların birleşerek dörtlüler olarak tartışmaya devam etmesini, dinleme üçlüleri etkinliği; konuşmacı, soru soran ve kaydeden olmak üzere bir araya gelen üçlü grup tartışmasını, elçiler etkinliği; argümanlar ve verilen kararlar hakkında gruplar arasında bilgi akışı sağlanmasını gerektirmektedir (Osborne, Erduran \& Simon, 2004). Bu etkinlikler çoğaltılıp farklılaştırılarak uygulanabilir.

Öğrenenlere pek çok olumlu özellik kazandırdı̆̆ı belirlenen argümantasyona dayalı öğretimin uygulanmasında bazı zorluklar da bulunmaktadır. Öğrencilerin farklı disiplin konularını bir araya getirmede güçlükler yaşaması, ele alınan konuyla ilgili olarak medya ve diğer bilgi kaynaklarının etkisiyle özgün fikirler oluşturmada yaşanan güçlükler, içe kapanık öğrencilerin kendilerini ifade etmede yaşadığı sorunlar, argümanları güçlü olsa da kendini daha iyi ifade edebilen ama zayıf argüman geliştirmiş öğrencilerin fikirlerini kabul ettirmesi, tartışma becerisi gerektirmesi, öne çıkan zorluklardır (Kolsto, 2004; Bell \& Lederman, 2003). Ayrıca okullarda bilimsel tartışma ve argümantasyona dayalı bir kültürün gelişmemiş olması, öğretmenlerin gerek kültürel gerek bilgi birikimi bakımından sorgulama ve tartışmaya dayalı öğretimi gerçekleştirmeye hazır olmaması da yaşanabilecek güçlükler arasında sayılmaktadır (Driver et al., 2001).

Yapılandırmacı eğitim anlayışına uygun ve çok yönlü gelişmeyi destekleyen argümantasyona dayalı öğretimin, sıklıkla fen alanında incelendiği (Osborne, 2010) görülmekle birlikte, bu alanda laboratuvar çalışmalarının yanı sıra nükleer santral yapımı, genetiği değiştirilmiş organizmalar, klonlama, çevre bilinci, kaçak elektrik kullanımı gibi sosyo-bilimsel konuların işlenmesinde daha fazla denendiği dikkat çekmektedir (Tezel \& Yılmaz, 2017). Yapılan araştırmalarda argümantasyona dayalı öğretimin; üniversite öğrencilerinin tartışma isteğini olumlu etkilediği (Baydaş, Yeşildağ Hasançebi \& Kilis, 2018), öğrenenlerin bilimsel süreç becerilerini (Duschl \& Osborne, 2002), kavramsal anlama yeteneklerini (Yerrick, 2000), başarılı ve geçerli argüman üretme yeterliklerini geliştirdiği (Nussbaum \& Sinata, 2008; Venville \& Dawson, 2010), öğrencilerin öğrenme sürecine aktif katılma isteğini (Kaya, Erduran \& Çetin, 2010; Martin \& Hand, 2009) ve fen başarısını artırdığı (Balcı \& Yenice, 2016; Cross \& Taasoobhirazi, 2008; Yeşildağ Hasançebi \& Günel, 2013; Yıldız \& Ünal, 2016) ortaya konmuştur. Argümantasyona dayalı öğretimin öğrenme fırsatlarını artırması bakımından öğrenciler tarafından olumlu bir uygulama olarak değerlendirildiği (Kıngır, Geban \& Günel, 2011), öğrenme sorumluluğunu alma, özgüven kazanma gibi özellikleri geliştirmede etkili bulunduğu (Kabataş \& Memiş, 2014) da ifade edilmektedir. Argümantasyona dayalı öğretimin zaman alıcı olması (Aktamış \& Atmaca, 2016; Simon \& Johnson, 2008) ise bu uygulamanın öne çıkan sınırlılı̆ı olarak ifade edilmektedir. Argümantasyona dayalı öğretim, uygun düzenlemelerle çeşitli derslerde uygulanabilmektedir. Grbovic ve Dragonic (2017), içinde bulunulan çevreyi tanıma, koruma, fırsatları fark etme bakımından öğrenciler için önemli olan coğrafya öğretiminde öğrenen merkezli eğitimin gerçekleştirilmesi gerekliliğine dikkat çekerek argümantasyona dayalı öğretimi önermektedir.

Coğrafya dersi, kendine özgü bir çalışma konusu olmasının yanı sıra fen konuları da dahil disiplinlerarası konuları içermesi, yaşama yakın ve karmaşık ilişkilerin anlaşımasını gerektirmesi bakımından öğrenciler için önemlidir. İklim değişikliği, doğal afetler, gıda güvenliği, beslenme, kentleşme, nüfus sorunları gibi konular coğrafya alanında disiplinlerarası yaklaşımla ele alınan konulardan bazılarıdır (Grobovicl \& Dragonic, 2017). 
Coğrafyayı önemli kılan sebeplerin başında insanlığın evi olarak da adlandırılan çevreye ilişkin kaynaklar, sürdürülebilir ekonomik fırsatlar, ekosistem, iklim, su kaynakları gibi pek çok önemli konuyu içermesi ve öğrenenlere bilginin yanı sıra dünya görüşü kazandırması gelmektedir. Bu süreçte mekânsal düşünme, mekânsal analiz, bütünsel düşünme, gerçek dünya sorunları hakkında düşünme, bireysel ve toplumsal kimliğin farkında olma becerilerinin kazandırılması da önem kazanmaktadır. Bu beceri ve özelliklerin kazandırılması sürecinde coğrafya öğretim programının öğrenci merkezli uygulanması gerektiği vurgulanmaktadır (Bonnett, 2008; Hicks, 2007; Maude, 2010). Coğrafya öğretim programında yer alan konuların argümantasyona dayalı öğretim açısından uygun olmasına rağmen Türkiye ve yurt dışında yapılan sınırlı sayıda çalışmada ele alındığı görülmektedir. Bu çalışmalardan Grboviç ve Dragoniz (2017) tarafından yapılan araştırma, betimsel tarama modelindedir ve Coğrafya dersinde öğrenci merkezli uygulamalar ile argümantasyona dayalı öğretime yer verilme düzeyi öğrencilere uygulanan ölçekle ortaya konmuştur. Nussbaum, Sinatra ve Owens (2012) öğrenciler tarafından üretilen argümantasyonların geçerlilik düzeyini, Venville ve Dawson (2010) ise argümantasyona dayalı öğretimin kalıc öğrenmeyi sağlamadaki etkisini, Torun ve Şahin (2016) de argümantasyona dayalı öğretimin öğrencilerin karar verme ve argüman düzeyleri üzerindeki etkisini incelemiştir. Görüldüğü gibi, alanyazında ulaşılan çalışmalar, argümantasyona dayalı öğretim uygulamasını belli açılardan incelemektedir. Durum çalışması şeklinde tasarlanan bu araştırmayla önceki çalışmalardan farklı olarak, argümantasyona dayalı öğretim uygulaması, öğrenci ve öğretmen bakış açısıyla birlikte ele alınmakta, uygulamada karşılaşılan güçlükler ve çözüm önerilerini ortaya koyması bakımından alanyazına katkı sunmaktadır. Bu bağlamda araştırmanın amacı; coğrafya dersinde argümantasyona dayalı öğretim sürecinde yaşananların öğrenci ve öğretmen bakış açısıyla analiz edilmesi, argümantasyona dayalı öğretim tasarımları oluşturma süreçlerine veri kaynağı sağlanmasıdır.

\section{Yöntem}

\section{Araştırmanın Deseni}

Argümantasyona dayalı öğretimin, öğrencilerin bu sürece ilişkin görüşleri, öğrenme ve gelişme süreçlerine katkısı ile uygulama öğretmeninin bu sürece ilişkin görüşlerini ortaya çıkarmayı amaçlayan bu çalışmada; tek bir analiz birimi bütüncül olarak incelendiği için nitel araştırma yöntemine uygun olarak bütüncül tek durum deseni (Yin, 2003) kullanılmıştır. İncelenen durum; argümantasyona dayalı öğretimin uygulandığı Coğrafya dersi, analiz birimi; bu dersin öğretim sürecindeki deneyimler ve tepkilerdir. Çalışmanın sınırlılıkları; uygulamanın haftada dört ders saati olup dört hafta sürmesi, "Mekansal Bir Sentez: Türkiye” ünitesinde, "Medeniyetlerin Merkezi Türkiye" ve "Türkiye'de Arazi Kullanımı" konularını kapsamasıdır. Uygulama sırasında, argümantasyona dayalı öğretimin gerçekleştirilmesinde temel etkinlikler olan ifadeler tablosu, kavram haritası, karikatürlerle yarışan teoriler, hikayelerle yarışan teoriler, tahmin et-gözle-açıkla, çift konuşması, çiftler dörtlere, dinleme üçlüleri, elçiler, rol oynama etkinlikleri gerçekleştirilmiştir.

\section{Katılımcılar}

Çalışmada, amaçlı örnekleme yöntemlerinden kolay ulaşılabilir durum örneklemesi kullanılmıştır. Bu yöntemde araştırmacı, erişilmesi kolay olan bir durumu seçip incelemektedir (Wildemuth, 2009). Araştırmanın katılımcılarını, Marmara Bölgesindeki bir devlet okulunda lise 11. sınıfta öğrenim gören 11 kız, 3 erkek toplam 14 öğrenci ile bir öğretmen oluşturmaktadır. Katılımcılarının çoğunluğunun kız öğrenci olması, bu çalışmanın bir diğer sınırııı̆ı olarak kabul edilebilir.

\section{Veri Toplama Araçları ve Verilerin Toplanması}

Diğer nitel araştırma yöntemlerinde olduğu gibi durum çalışmalarında da verilerin çeşitli kaynaklardan elde edilmesi önemlidir (Yin, 2003). Bu araştırmada veri çeşitlemesi için öğrencilerle yarı yapılandırılmış görüşme gerçekleştirilmiş, uygulama süresince öğretmen tarafından yapılandırılmamış günlük tutulmuştur. Görüşme formunu hazırlamak için öncelikle alan yazın incelenmiş, eğitim programları ve öğretim alanında uzman iki öğretim üyesinin görüşleri alınmıştır. Formda, öğrencilerin argümantasyona dayalı eğitime ilişkin görüşlerini belirlemek amacıyla beş soruya yer verilmiştir. Görüşmeler, 25-30 dakika arası sürmüş, ses kaydı alınmıştır. Araştırmacılar tarafından yazılı hale getirilen görüşmelerin katılımcılar tarafından kontrol edilmesi sağlanmıştır.

Diğer veri toplama aracı, öğretmen günlüğüdür. Uygulama için seçilen Coğrafya dersi öğretmenine uygulama öncesi 10 saat süren bir eğitim verilmiştir. Bu eğitimde argümantasyona dayalı öğretim, uygulama örnekleri, ifadeler tablosu, kavram haritası, karikatürlerle yarışan teoriler, hikayelerle yarışan teoriler, tahmin 
et-gözle-açıkla, çift konuşması, çiftler dörtlere, dinleme üçlüleri, elçiler, rol oynama bu süreçte dikkat edilmesi gereken konular hakkında bilgilendirme gerçekleştirilmiştir. Uygulamayı yapan öğretmen yüksek lisans derecesine sahiptir. Uygulama, “Mekansal Bir Sentez: Türkiye” ünitesinde, “Medeniyetlerin Merkezi Türkiye” ve "Türkiye'de Arazi Kullanımı" konularında haftada dört ders saati olmak üzere dört haftada tamamlanmıştır. Süreç boyunca öğretmen tarafından, uygulamada karşılaşılan güçlükler, olumlu yönler ve sınıf içinde dikkat çeken diğer durumlara ilişkin günlük tutulmuştur.

\section{Verilerin Çözümlenmesi}

Araştırmada kodlamaya dayalı tümevarımcı içerik çözümlemesi gerçekleştirilmiş, öğrencilerle yapılan görüşmeler ve öğretmen günlüklerinden elde edilen veriler bütüncül biçimde yorumlanmıştır. Yapılan kodlamalar sonrası oluşan temalar üzerinde araştırmacıların \%81 uyuştuğu (Miles \& Huberman, 1994) belirlenmiştir.

\section{Geçerlik ve Güvenirlik}

$\mathrm{Bu}$ araştırmada kodlamalar üzerindeki görüş birliğinin \%81 olması iç tutarlılık, sürecin ayrıntılı biçimde açıklanarak ses kayıtları, yazılı hale getirilen formların üzerine alınan kodlama notlarıyla olası kontroller için saklanması teyit edilebilirlik, katılımcı teyitlerinin alınması ve katılımcı ifadelerinden örneklerin doğrudan alıntılar biçiminde değiştirilmeden yapılması inandırıcılık, araştırmanın gerçekleştirilme süreci, deseni, katılımcılar, veri toplama, veri çözümleme süreçlerinin açıklanması aktarılabilirlik göstergesi olarak kabul edilebilir.

Kısaltmalar: Öğrenci görüşleri alıntılanırken Ö1, Ö2 olarak kısaltma yapılmıştır.

\section{Bulgular}

Araştırmada, öğrenci görüşmeleri sonunda oluşturulan transkriptler ile öğretmen günlükleri incelenmiş, temalar her iki veri kaynağından elde edilen verilerin bütünsel olarak incelenmesiyle oluşturulmuştur. Buna göre; Argümantasyonun Öğretim Sürecine Katkıları, Argümantasyona Dayalı Öğretim Sürecindeki Sınırlılıklar ve Öneriler temaları oluşmuştur. Her temayı oluşturan kodlara ilişkin örnek öğrenci görüşlerine ve öğretmen günlüğünde yer alan ifadelere herhangi bir değişiklik yapılmadan yer verilmiştir.

\section{Argümantasyonun Öğretim Sürecine KatkılarıTema'sına îlişkin Bulgular}

Bu temayı oluşturan kodlar; eğlenme, kalıcı öğrenme, hayal gücü, özgüven, katılım, arkadaşlık, eleştirel düşünmedir. Görüşmelerde argümantasyona dayalı öğretim sürecinde öğrenciler sıklıkla eğlendiklerini belirtmişlerdir. Örneğin Ö1 “... ben okulda bu türden etkinlikleri yapmayı seven biriyim. Çünkü okulun münazara takımında da olduğum için böyle konuşmak falan çok güzeldi. Dersler çok eğlenceli geçti...” ve Ö5 “... sıkılmadan eğlenerek öğrendiğimi söyleyebilirim..." biçiminde görüş belirterek derslerin eğlenceli geçtiğine vurgu yapmışlardır. Nitekim öğretmen günlüğünde de “...öğrencilerin eğlenerek öğrendiğine şahit oluyorum...”, “... öğrenciler derslerde hem aktifler, hem eğleniyorlar..." ifadeleri bulunmaktadır. Bu bakımdan öğretmen ve öğrencilerin uygulamanın eğlenceli olduğuna ilişkin görüşleri tutarlıdır.

Katılımcıların görüşlerinin birleştiği diğer konu, kalıcı öğrenmenin gerçekleşmesi olmuştur. Ö8 “... bu sayede kendi görüşümüzü belirtirken farklı görüşlere karşı kendimizi de savunduk. Öğrendiklerimiz kesinlikle kalıcı oldu çünkü üzerinde çok fazla tartıştık, konuştuk...”, Ö3 “... çok faydalıydı çünkü daha akılda kalıcı olduğunu düşünüyorum. Kimse düşüncesini saklamadı ve de eksik kaldığımız yerde birbirimizi tamamladık...", Ö11 "... diğer derslere göre daha fazla söz hakkım oldu, daha fazla katıldım, daha iyi öğrendim, unutmam artık..." ifadelerini kullanmışlardır. Öğretmen günlüğünde de bu temayla ilgili ifadelerin bulunduğu görülmüştür. "... özellikle bugün kendi medeniyetini kurmaya var mısın? etkinliğinde öğrencilerin iddialarını neden ve sonuçlarıyla ortaya koyması ve birbirlerinin görüşlerini çürütmeye çalışmaları etkileyiciydi. Etkinlik sırasındaki aktif katılımları, fikir alışverişi yapmaları, görüşlerini savunmak zorunda olmaları öğrendiklerinin kalıcı olmasını sağlıyor...", "... bu yöntemden tarih öğretmeni S. ve Türk Dili Edebiyatı öğretmeni D. hanıma mutlaka söz edeceğim. Kalıcı öğrenmenin gerçekleşmesi için kullanılması gerekir..."

Argümantasyona dayalı öğretimin hayal gücünü geliştirdiği sıklıkla ifade edilmiştir. Ö6 "... hem 40 dakika boyunca ders dinlemektense çok çok düşündük, bir şeyler öğrendik, çözümleri hayal ettik. Bu kadar hayal 
edebildiğimi bilmiyordum..." biçiminde görüşünü belirtirken öğretmen günlüğünde de “... farklı bakış açılarıyla yaklaşmayı öğreniyorlar, hayal güçleri beni şaşırtmaya başladı..." ifadeleri yer almıştır.

Dikkat çeken diğer tema özgüven olmuştur. Ö2 “... kendi düşünemediğimiz şeyleri arkadaşlarımızdan duyarak daha çok bilgi edindik. Ben çok konuşmayı sevmem ama tartışarak ders işlendiği için benim de görüşler öne sürmem gerekti ve gitgide kendime güvenim geldi...", Ö14 “... zamanla herkesin içinde konuşacak güven de geliyor insana..." biçiminde ifadeler kullanmıştır. Argümantasyona dayalı öğretimin arkadaşık ilişkilerini olumlu etkilediği ifade edilmiştir. Ö9 "...mesela sevmediğin bir insanla aynı grupta olabiliyosun. Kötü biri olmadığını anlıyorsunuz ya da olumlu yönleri de olduğunu görüyosunuz. Iyi bir şey bence..." ve Ö10 “... sınıf bir paylaşım yeri oluyor, arkadaşılık etmediğin kimselerle de arkadaş oluyorsun..." biçiminde görüş belirtmiştir. Öğretmen günlüğünde de "...Fikir alışveriş̧ yapmaları farkı görüşlere saygı duymayı da öğretiyor. Arkadaşlık duygularının geliştiğini görüyorum..." ifadeleri yer almıştır.

Eleştirel düşünme becerilerinin geliştiği hem öğretmen hem öğrenciler tarafından ifade edilmiştir. Ö4 “... Iyi bir yöntem bence çünkü her öğrencinin fikrini ortaya koymasını hepsinin özgür düşünmesini sağlıyo; çünkü normalde sözel derslerde mesela genellikle öğretmen, bilgiyi anlatıyo ama bu yöntemde her öğrenciye fikir özgürlügü var ve eleştirel bir ortam oluşturuyo...", Ö7 “... konuya kapsamlı bakmak gerekiyor. Arkadaşlarımızın fikrini eleştirip kırmadan reddettik bazen...", Ö10 "...Genel olarak coğrafyanın ezbere dayalı olduğunu düşünüyorum. Ezberleyince de sınavdan sonra unutuyoruz. Argümantasyonda en azından eleştirel bakıyoruz, birbirimizin fikrini alıyoruz. Sınıf bir paylaşım yeri oluyor..." ifadelerini kullanmıştır. Öğretmen günlüğünde de “... Çeltik Tarlaları Büyük Zarar Gördü" isimli etkinlikte savcı-hâkim ve avukat rolüyle eleştirel düşünebildiklerini, aslında savunmak zorunda olduğu fikre sahip olmasa da o taraftan bakabilmeye çalıştıklarını gördüm..." ifadesinin öğrenci görüşlerini destekler nitelikte olduğu görülmüştür.

\section{Argümantasyona Dayalı Öğretim Sürecindeki Sınırılıklar Tema'sına İlişkin Bulgular}

Bu tema, çatışma, öğretmenden dinleme gereksinimi, zaman alıcı kodlarıyla oluşturulmuştur. Katılımcıların, sınıfta zaman zaman çatışma oluştuğu, öğretmenden dinleme gereksinimi duyulduğu ve etkinliklerin zaman alıcı olduğu, sürenin bazen yetmediği şeklindeki görüşleri, uygulamanın olumsuz yönlerini ortaya koymuştur. Ö1 “...böyle ders işlemenin zorlukları kişsisel olarak yok da, grup içinde bazen anlaşmazlıklar çıkabiliyor. Çünkü hepimizin görüşleri farklı oluyor. Mesela arkadaşlarıma göre ben biraz daha kendi başıma halletmeyi seven bir insan olduğum için grup çalışmasında biraz zorlanabiliyorum...", Ö9 " ...ya aslında hımmm nasıl anlatayım nerdeyse kavga çıkıyor bazen..." şeklinde görüşünü açıklamıştı. Öğretmen günlüğünde yer alan "...eleştiriyi kaldıramayan öğrencilerim de yok değil. Bugün A.'nın görüşü beğenilmeyince sinirlendiğine ve tartıştığına şahit oldum..." ifadeler de sınıfta tartışmaların ortaya çıktığını göstermiştir. Öğretmenin daha fazla anlatım yapmasına gereksinim duyan öğrencilerin olduğu Ö6 "öğretmen çok az şey anlattı, yetersizdi bence.." ve Ö13 “... beş dakikalık bir anlatım üzerine biz bir şeyler yapmaya çalıştık. Bence bu daha fazla olması gerekli. Bunun için de ders lazım ama tabi..." ifadelerinden anlaşılmıştır. Ö8 "... bir de ders saatleri hiç yetmiyor. Hani gelip hazırlanmamız, düşünmemiz, düşüncemizi ortaya atmamı derken zaman geçiyor. Teneffüsler falan araya girdiği için biraz sıkıntı yaşadık bu konuda..." ve Ö12 "... belki uzun olsaydı biraz ders saati daha farkı fikirler de ortaya çıkabilirdi. Ya da daha fazla kaynaktan yararlanacak zaman da olurdu yani fikirlerimizi desteklemek için daha iyi sunumlar yapabilirdik o zaman...", Ö13 “... zaman alıyor biraz. Yani direkt anlatılarak geçilecek konular, işlenerek geçildiği için daha fazla zaman alıyor..." diyerek süre yetersizliği konusundaki görüşlerini ortaya koymuştur. Öğretmen günlüğünde bu konuyla ilgili olarak "Etkinlikler uzun zaman alıyor. Bir ara zaman yetmeyince tartışmaya whatsapp üzerinden mi devam etsek diye düşündüm. Ya da görüntülü konferans da gerçekleştirebiliriz... Tartışma konularına yönelik bilgi ve dokümanları Facebook üzerinden bir grup oluşturarak gönderebiliriz böylece zamanı daha iyi kullanabiliriz..." ifadeleri yer almıştı. Bu ifadeler, öneriler temasının oluşturulmasında da etkili olmuştur.

\section{Öneriler Tema'sına ilişkin Bulgular}

Katılımcıların uygulamanın daha verimli olması açısından bazı öneriler getirdiği saptanmıştır. Öğretmen günlüğünde yukarıda da belirtilen teknolojiden yararlanarak zamanı etkili kullanma önerisinin yanı sıra “...küçük grup tartışmaları esnasında müzik ve videolardan daha fazla yararlanacağım. Olumlu bir atmosfer yaratmamız Iazım çünkü gergin olabiliyorlar öneriler tartışıırken.." ifadelerinin de yer aldığı görülmüştür. Bu temayla ilgili olarak Ö2 "...görsel malzeme daha çok kullanılabilir. Tiyatro olsun ya da böyle hani müzik falan filan olsun. Onun gibi geliştirilebilir...", Ö6 “...daha böyle bir teknolojik ortamda uygulanırsa eğer, bilgisayarın olduğu, internetin olduğu bir ortamda uygulanırsa o an kendi düşünceniz hakkında, kendi savunduğunuz fikir hakkında kanıtlar 
bulabiliriz kendimize. Ya da o an birisiyle görüşerek, kamera üzerinden görüşserek başka uzakta birisiyle ondan bilgi edinebiliriz...", Ö7 "...yani sosyal medyadan da gördügümüz bi şeyden hani desteklemek amaçlı onu da koyabiliriz hani böyle bir durum varmış diyerekten ya da böyle böyle bir durum yaşanmış gibilerinden olabilir diye düşünüyorum. Örneklerle desteklemek amacılla yani...", Ö11 “...mesela okul tabletlerini getirerek şey yapabiliriz. Nasıl desem... her grubun mesela oradan da bilgi alışverişi yapabiliriz..." ifadeleriyle önerilerde bulunmuştur.

\section{Tartışma, Sonuç ve Öneriler}

Bu çalışmada, argümantasyona dayalı öğretimin coğrafya öğretim programında uygulanmasının öğrenciler tarafından genel olarak olumlu bulunduğu ve uygulamayı gerçekleştiren öğretmen günlüğünde de öğrencilerin görüşleriyle benzer sonuçlara ulaşıldığı görülmüştür.

Katılımcılar, argümantasyona dayalı öğretim sırasında aktif katılım göstermekten keyif alarak, eğlenceli bir süreçte kalıcı öğrenmeler gerçekleştirdiklerini ifade etmişlerdir. Kaya, Erduran ve Çetin (2010) ile Martin ve Hand (2009) tarafından yapılan çalışmalarda da katıımcıların aktif katılımdan keyif aldıkları ifade edilmektedir. Benzer şekilde Aktamış ve Atmaca (2016) ile Kabataş ve Memiş (2014) de kalıcı öğrenmenin gerçekleşmesinde argümantasyona dayalı öğretimin etkili olduğunu vurgulamaktadır. Venville ve Dawson (2010) da, üzerinde tartışma yapılan konuların kalıcı biçimde öğrenildiğini belirtmektedir. Bu bağlamda argümantasyona dayalı öğretimin, yapılandırmacı anlayışa uygun eğitim uygulamalarında ve aktif öğrenmenin gerçekleştirilmesinde anahtar role sahip olduğu söylenebilir.

Öğrencilerin akranlarıyla argümantasyona dayalı olarak bilimsel tartışmalar gerçekleştirmesi, onların etkin bir süreçte kavramları daha iyi anlamasını sağlamaktadır (Canpos, Silva, Tecpan \& Zacla, 2016). Bu sürecin etkisinin artırıması için çalışma yaprakları, yazma, listeleme gibi görevlerin de verilmesi önerilmektedir (Keys, Hand, Prain \& Collins, 1999). Bu çalışmada da etkinlikler sırasında öğrencilerin çalışma yapraklarındaki görevleri yerine getirmiş olması, onların kalıı öğrendiklerini ifade etmelerini sağlamış olabilir.

Araştırmada katııımcılar, argümantasyona dayalı öğretimin eleştirel düşünme becerisini geliştirdiğini ifade etmiştir. Argümantasyona dayalı öğretim sürecinde öğrenenler, eleştirel ve yansıtıcı düşünme gibi üst düzey düşünme becerilerini işe koşmak durumundadır. Nitekim, Andrews (2015), Duschl ve Osborne (2002), Glassner ve Schwarz (2007), Lazarou, (2010) da çalışmalarında benzer sonuçlara ulaşmıştır. Her kademedeki öğretim programlarında eleştirel düşünme becerisinin geliştirilmesinin vurgulandığı dikkate alındığında öğretim sürecinin tasarlanmasında argümantasyona dayalı öğretim uygulamalarına yer verilmelidir. Bu durum, öğretmen eğitim programlarına da yansıtılmalı, hizmet öncesi ve hizmet içi öğretmen eğitiminde argümantasyona dayalı öğretim uygulama becerilerinin kazandırılması sağlanmalıdır.

Araştırmada, argümantasyona dayalı öğretimin, olaylara farklı bakış açılarıyla yaklaşmayı sağlama ve hayal gücünü geliştirmede etkili olduğu belirlenmiştir. Aktamış ve Atmaca (2016) da benzer bulgulara dikkat çekmektedir. Öğrencilerin, argümantasyona dayalı öğretim sürecinde, yapılandırmacı eğitim anlayışının ve sosyal öğrenmenin önemli vurgularından olan bu özellikleri geliştirdiğini fark etmeleri, onların sadece uygulanan öğretim programı açısından değil kişisel gelişimleri açısından da önemlidir. Ayrıca bu bulgu, Bean (1996), Chen ve She (2012) ile King (2000)'in argümantasyona dayalı öğretimin, öğrencilerin kanıtlar üzerinde düşünmelerini, çelişen düşünceleri belirlemelerini, alternatifleri hayal etmelerini, durumlara farklı bakış açılarıyla yaklaşmalarını sağladığı yönündeki ifadeleriyle tutarlıdır.

Genel olarak hem uygulamayı yapan öğretmen hem öğrenciler olumlu yönlere vurgu yapmakla birlikte, ders süresinin uygulamalar açısından yeterli olmadığı ve öğrenciler arasında zaman zaman çatışma yaşandığı da belirtilmiştir. Alanyazında da uygulamaların zaman alıcı olduğunu ifade eden çalışmalar bulunmaktadır (Aktamış \& Atmaca, 2016; Simon \& Johnson, 2008; Torun \& Şahin, 2016). Uygulamanın bu sınırlılı̆ının giderilebilmesi için etkili bir zaman yönetimi ve ayrıntılı planlama yapılmalıdır. Öte yandan ele alınacak sorun durumlar, alt sorunlara ayrıldıktan sonra argümantasyona dayalı öğretim süreci gerçekleştirilebilir. Ayrıca teknolojiden yararlanılarak, sınıfta belirli bir aşamaya gelinen tartışma, sosyal medya gibi çeşitli uygulamalar aracılığıyla uzaktan tamamlanabilir. Zaman yetersizliği sorunu, argümantasyona dayalı öğretimin farklı öğretim programlarında yaygın biçimde kullanılmaya başlanmasıyla azalabilir. Argümantasyona dayalı öğretimin yaygın olarak uygulanmaması, sürenin yetersiz kalmasında bir etken olabilir. Öğrenciler ne kadar çok uygulama ile karşılaşırsa argüman ve karşı argüman üretmede o kadar yetkin hale gelecektir. Böylelikle zaman yönetimi konusundaki sorunlar giderilebilir. Nitekim Torun ve Şahin (2016) sosyal bilgiler dersinde zaman içinde öğrencilerin argümantasyon becerilerinin geliştiğini, Crowell ve Kuhn (2012) da argümantasyonun zamanla gelişen bir beceri olduğunu ifade etmiştir. 
Argümantasyona dayalı öğretimin birçok olumlu özelliği sıralansa da bazı öğrenciler öğretmenden ders dinleme gereksinimi duyduklarını ifade etmişlerdir. Bu bulgu, öğrenme stillerinin ve farklı öğrenme tercihlerinin göz ardı edilmemesi gerektiğini hatırlatır niteliktedir. Öğretim sürecinde tek bir yöntem ya da uygulamanın seçilmesi bazı öğrencilerin süreçten etkin yararlanamamasına sebep olmaktadır. Bu durumda argümantasyona dayalı eğitimin tek başına değil, farklı yöntem ve tekniklerle birleştirilerek uygulanması yoluna gidilebilir. Tek bir derste farklı öğrenme stillerinin ve tercihlerinin dikkate alınabildiği türde planlama yapma olanağı veren deneyimsel öğrenme döngüsüne uygun tasarımlarla desteklenen argümantasyon uygulamaları denenebilir. Bu bağlamda, farklı yöntem, teknik ve modellerle denenen argümantasyona dayalı öğretimin etkililiği konusunda bilimsel çalışmaların sürdürülmesi gereklidir.

$\mathrm{Bu}$ araştırmada, coğrafya dersinde argümantasyona dayalı öğretim uygulaması hem öğrenciler hem uygulama öğretmeni tarafından genel olarak olumlu değerlendirilmiştir. Bununla birlikte, alanyazında coğrafya, tarih, sosyal bilgiler gibi derslerde argümantasyona dayalı öğretimin etkisinin ortaya konduğu, uygulama sürecindeki olumlu ve sınırlı yönlerinin incelendiği çalışma sayısı son derece sınırlıdır. Fen alanında birçok farklı değişken açısından incelenen bu uygulamanın, sosyal bilimler alanında da yaygınlaşmasına katkı sağlayacak çalışmaların yapılması önerilebilir. Ayrıca bu araştırmada hem öğrencilerin hem öğretmenin süreçte bazı çatışmaların yaşandığını ifade ettiği göz önüne alındığında, çatışma çözme stratejileri ve akran arabuluculuk eğitiminin de verilmesi gerektiğini düşündürmektedir. Katılımcılar, uygulama sırasında zamanın yetersiz kaldığını ifade etmiştir. Zaman yönetimi stratejileri eğitiminin sağlanması, argümantasyona dayalı öğretim uygulamalarında karşılaşılan bu sorunun giderilmesine katkı sağlayabilir. Argümantasyona dayalı öğretimin bilişsel, duyuşsal ve psikomotor öğrenmeler üzerindeki etkilerinin incelendiği deneysel çalışmalar ile söz konusu süreçleri inceleyen nitel çalışmalar, alanyazındaki bilgi birikimine katkı sağlayıcı olacaktır.

\section{Bilgilendirme}

Bu çalışmanın bir kısmı 5. Uluslararası Eğitim Programları ve Öğretim Kongresinde sözlü bildiri olarak sunulmuştur. 


\section{References}

Aktamış, H., \& Atmaca, A. C. (2016). Fen bilgisi öğretmen adaylarının argümantasyon tabanlı öğrenme yaklaşımına yönelik görüşleri. Elektronik Sosyal Bilimler Dergisi, 15(58), 936-947.

Andrews, R. (2015). Critical thinking and/or argumentation in higher education. In M. Davies \& R. Barnett (Eds), The palgrave handbook of critical thinking in higher education (pp.49-62). Palgrave Macmillan.

Andriessen, J. (2006). Arguing to learn. In R.K. Sawyer (Ed.), The Cambridge handbook of the learning sciences (pp. 443-460). New York: Cambridge University Press.

BalcI, C., \& Yenice, N. (2016). Effects of the scientific argumentation-based learning process on teaching the unit of cell division and inheritance to eighth grade students. Journal of Education in Science, Environment and Health, 2(1), 67-84.

Baydaş, Ö., Yeşildağ Hasançebi, F., \& Kilis, S. (2018). Argümantasyon tabanlı bilim öğrenme yaklaşımında üniversite öğrencilerinin tartışma süreçlerinin incelenmesi. Inönü Üniversitesi Eğitim Fakültesi Dergisi, 19(3), 564-581.

Bean, J. C. (1996). Engaging ideas: The professor's guide to integrating writing, critical thinking, and active learning in the classroom. San Francisco: Jossey-Bass.

Bell, P., \& Linn, M. C. (2000). Scientific arguments as learning artifacts: Designing for learning from the web with KIE. International Journal of Science Education, 22 (8), 797-817.

Bell, R.L., \& Lederman, N.G. (2003). Understandings of the nature of science and decision making on science and technology-based issues. Science Education, 87, 352-377.

Bonnett, A. (2008). What is geography? London: Sage.

Burke, K. A., Greenbowe T. J., \& Hand, B. M. (2006). Implementing the science writing heuristic in the chemistry laboratory. Journal of Chemical Education, 83(7), 1032-1038.

Campos, E., Silva, L., Tecpan, S. \& Zavala, G. (2016). Argumentation during active learning strategies in a SCALEUP environment. In Ding, J. (Ed.) Physics Education Research Conference Proceeding (pp. 64-67). California: Sacramento.

Chen, C. H., \& She, C. (2012). The impact of recurrent online synchronous scientific argumentation on students' argumentation and conceptual change. Educational Technology \& Society, 15(1), 197-210.

Choi, A., Hand, B., \& Norton-Meier, L. (2014). Grade 5 students' online argumentation about their in-class inquiry investigations. Research in Science Education, 44(2), 267-287.

Cross, D., Taasoobshirazi, G., Hendricks, S., \& Hickey, D. (2008). Argumentation: A strategy for improving achievement and revealing scientific identities. International Journal of Science Education, 837-861.

Crowell, A.I \& Kuhn, D. (2012). Developing dialogic argumentation skills: A three-year intervention study. Journal of Cognition and Development, 15(2), 363-381.

Driver, R., Newton, P., \& Osborne, J. (2000). Establishing the norms of scientific argumentation in classrooms. Science education, 84(3), 287-312.

Duschl, R. A. \& Osborne, J. (2002). Supporting and promoting argumentation discourse in science education. Studies in Science Education, 38, 39-72.

Felton, M. (2005). Thinking classroom. Washington, 6(4), 6-13.

Fisher, A. (2004). The logic of real argument. Cambridge: Cambridge University Press.

Freeley, A. J., \& Steinberg, D. L. (2013). Argumentation and debate, critical thinking for reasoned decision making. Wadsworth Cengage Learning.

Glassner, A., \& Schwarz, B. B. (2007). What stands and develops between creative and critical thinking? Argumentation? Thinking Skills and Creativity, 2(1), 10-18.

Grbovic, S. M., Dragonic, M. J. (2017). Student centered factors of geography teaching from the students' perspective. Nastava i vaspitanje, 66(3), 527-546.

Hicks, D. (2007). Lessons for the future: A geographical contribution. Geography, 82, 179-188

Jonassen, D., \& Kim, B. (2010). Arguing to learn and learning to argue: design justifications and guidelines. Educational Technology: Research and Development, 58(4), 439-457. 
Kabataş Memiş, E. (2014). Illköğretim öğrencilerinin argümantasyon tabanlı bilim öğrenme yaklaşımı uygulamalarına ilişkin görüşleri. Kastamonu Eğitim Dergisi, 22(2), 401-418.

Kaya, E., Erduran, S., \& Çetin, P. S. (2010). High School students' perceptions of Argumentation. Procedia Social and Behavioral Sciences, 2(2), 3971-3975.

Keys, C., Hand, B., Prain, V., \& Collins, S. (1999). Using the science writing heuristic as a tool for learning from laboratory investigations in secondary science. Journal of Research in Science Teaching, 36, 1065-1084.

King, P. M. (2000). Learning to make reflective judgments. In M. B. Baxter Magolda (Ed.), Linking student development, learning, and teaching: New directions for teaching and learning (Vol. 82, pp. 15-26). San Francisco: Jossey-Bass.

Kıngır, S., Geban, Ö., \& Günel, M. (2011). Öğrencilerin kimya derslerinde argümantasyon tabanlı bilim öğrenme yaklaşımın uygulanmasına yönelik görüşleri. Selçuk Üniversitesi Ahmet Keleşoğlu Eğitim Fakültesi Dergisi, 32, 15-28.

Kolsto, S. D. (2004). Students' argumentation: Knowledge, values and decisions. In E. K. Henriksen \& M. Odegaard (Eds.), Naturfagenes didaktikk-en disciplin iforandring? Det7. nordiske forskersymposiet om undervisning i naturfag i skolen (pp. 63-78). Kristiansand, Norway: Hoyskoleforlaget AS.

Kuhn, D., Iordanou, K., Pease, M., \& Wirkala, C. (2008). Beyond control of variables: What needs to develop to achieve skilled scientific thinking? Cognitive Development, 23(4), 435-451.

Lazaro, D. (2010). Learning to TAP: An effort to scaffold students' argumentation in science. In G. Çakmakçı, \& M.F. Taşar (Eds.), Contemporary science education research: scientific literacy and social aspects of science, a collection of papers presented at ESERA 2009 conference (pp.43-50). Ankara: Pegem Akademi.

Martin, A. M., \& Hand, B. (2009). Factors affecting the implementation of argument in the elementary science classroom. A longitudinal case study. Research in Science Education, 39(1), 17-38.

Maude, A. (2010). What does geography contribute to the education of young Australians? Geographical Education, 23, 14-22.

McNeill, K. L., Lizotte, D. J., \& Krajcik, J. (2006). Supporting students' construction of scientific explanations by fading scaffolds in instructional materials. The Journal of the Learning Sciences, 15(2), 153-191.

Miles, M. B., \& Huberman, M. A. (1994). An expanded sourcebook qualitative data analysis. London: Sage.

Noroozia, O., Weinbergerb, A., Harm, B., Muldera, M., \& Chizari, M. (2012). Argumentation-based computer supported collaborative learning: A synthesis of 15 years of research. Educational Research Review, 7, 79106.

Nussbaum, E. M., Sinatra, G. M. \& Owens, M. C. (2012). The two faces of scientific argumentation: Applications to global climate change. In M.S. Khine (Ed.), Perspectives on scientific argumentation: Theory, practice and research (pp. 17-37). Dordrecht: Springer.

Osborne, J. (2010). Arguing to learn in science: The role of collaborative, critical discourse. Science, 328(5977), 463-466.

Osborne, J., Erduran, S., \& Simon, S. (2004). Enhancing the quality of argumentation in school science. Journal of Research in Science Education, 41(10), 994-1020

Simon, S., \& Johnson, S. (2008). Professional learning portfolios for argumentation in school science. International Journal of Science Education, 30(5), 669-688.

Simon, S., Erduran, S., \& Osborne, J. (2006). Learning to teach argumentation: Research and development in the science classroom. International Journal of Science Education, 28, 235-260.

Tezel, Ö., Yılmaz, G. (2017). Türkiye'de argümantasyona dayalı fen bilimleri öğretimi çalışmalarından bir derleme. Eğitim ve Öğretim Araştırmaları Dergisi, 6(1), 146-160.

Torun, F., Şahin, S. (2016). Determination of students' argument levels in argumentation-based social studies course. Education and Science, 41(186), 233-251.

Toulmin, S. (1964). The uses of argument. Cambridge: Cambridge University Press.

Toulmin, S. (2001), Return to reason, Cambridge, London: Harvard University Press.

Venville, G. J., \& Dawson, V. M. (2010). The impact of a classroom intervention on grade 10 students' argumentation skills, informal reasoning, and conceptual understanding of science. Journal of Research in Science Teaching, 47(8), 952-977. 
Voss, J. F., \& Van Dyke, J. A. (2001). Argumentation in psychology: Background comments. Discourse Processes, 32(3), 89-111.

Wildemuth, B. M. (2009). Applications of social research methods to questions in information and library science. Westport, CT: Libraries Unlimited.

Yerrick, R. K. (2000). Lower track science students' argumentation and open inquiry instruction. Journal of Research in Science Teaching, 37(8), 807-838.

Yıldız, K., \& Ünal, Ş. (2016). Biyoloji dersi çevre konularının öğretiminde örnek olay inceleme ve argümantasyon yöntemlerinin etkisi. Informal Ortamlarda Araştırmalar Dergisi, 1(1),25-51.

Yin, R. K. (2003). Case study research design and methods. London: Sage Publications.

Zohar, A. (2004). Elements of teachers' pedagogical knowledge regarding instruction of higher order thinking. Journal of Science Teacher Education, 15(4), 293-312.

Zohar, A., \& Nemet, F. (2002). Fostering students' knowledge and argumentation skills through dilemmas in human genetics. Journal of Research in Science Teaching, 39(1), 35-62. 


\section{Ekler}

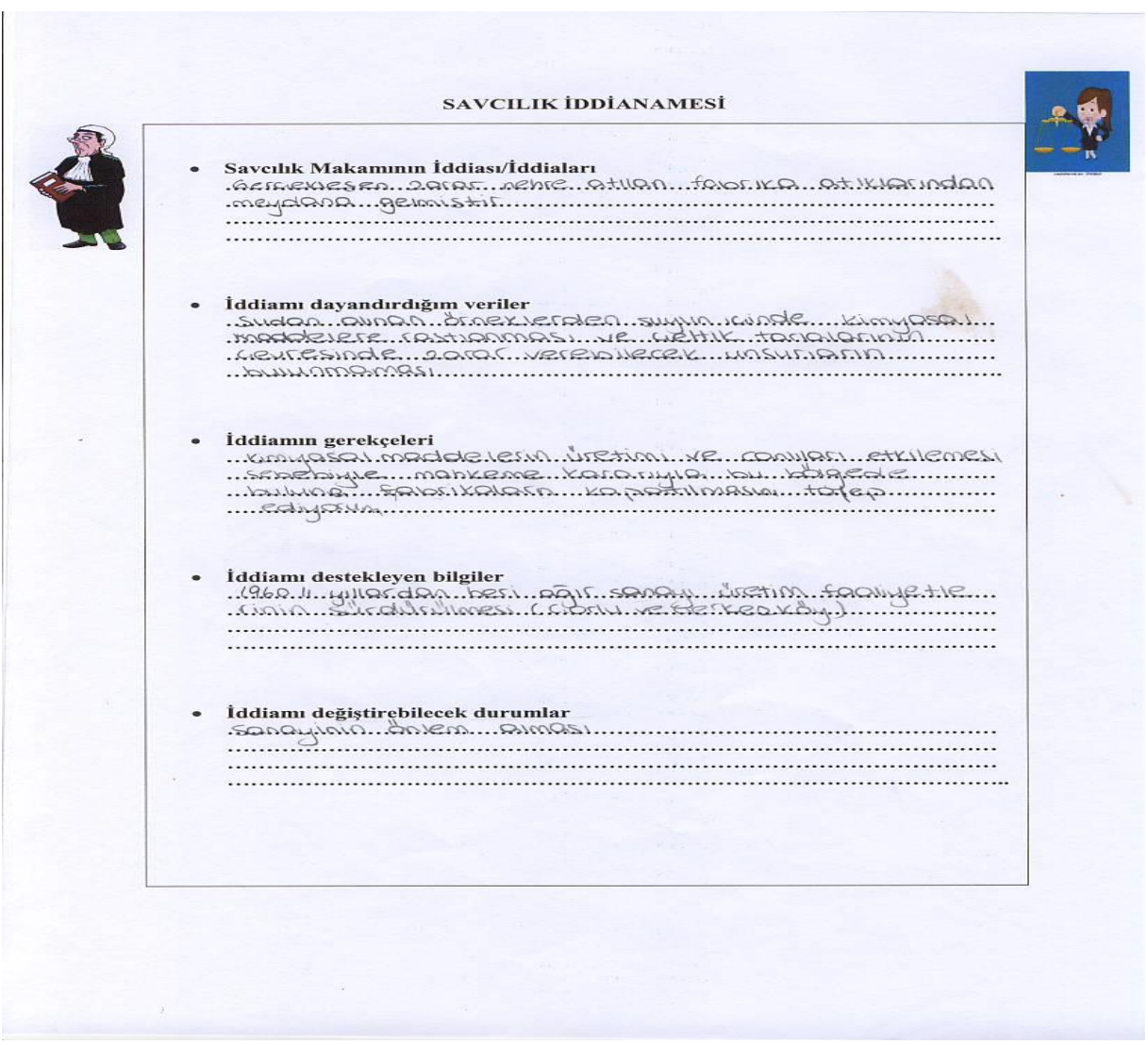

KAHIRE GRUBU

$$
\text { problemLer- ÇÖZÜMLER }
$$

(*)Tükiye'de sanayilesmeye verilen önem nedeniyle tesisler ços̆unlukla en yüksek getirileri sağlayacak alanlarda kurulmustur. Bu bağlamda, düzlök olması, kolay insaat yapıliması, karayollarina kaplanmaya alanlara olan gö́c hizlanmıstır. Böylece, eskiden genellikle ovaları cevreleyen yamaç alanlarında ver alan

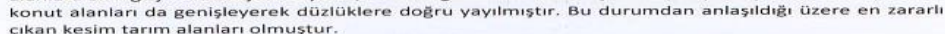

Türkive, uzun süre tarım ürünleri açısından kendine yeterli olmustur. Ancak, bazı sorunlar,
nüfus artisı ve yaniıs uygulamalar sonucunda gunoumuzde buëday gibi bazı temel tarim urünlerinin ithalini zorunlu hale getirmistsir. Tarım alanlarını etkileyen basslica fiziksel sorunlaraerozyondkurakitik gibi toprak yapisini ve bitkileri doğrudan etkileyen raktorieri onnek olarak verebiliziz. Bumlarin yaninda vaps, bozumaktadir Ayrica oretilen bitkilerin hizl büyümesi icin verilen hormon ilaclari onu tüketen insanlara geçmekte ve uzun vadede hastaliklara yol açabilmektedir. Zarariı böceklere karși kullanılan böcek öldürücüler de (pestisidler) akarsularla uzak mesafelere taşınmaktadir.
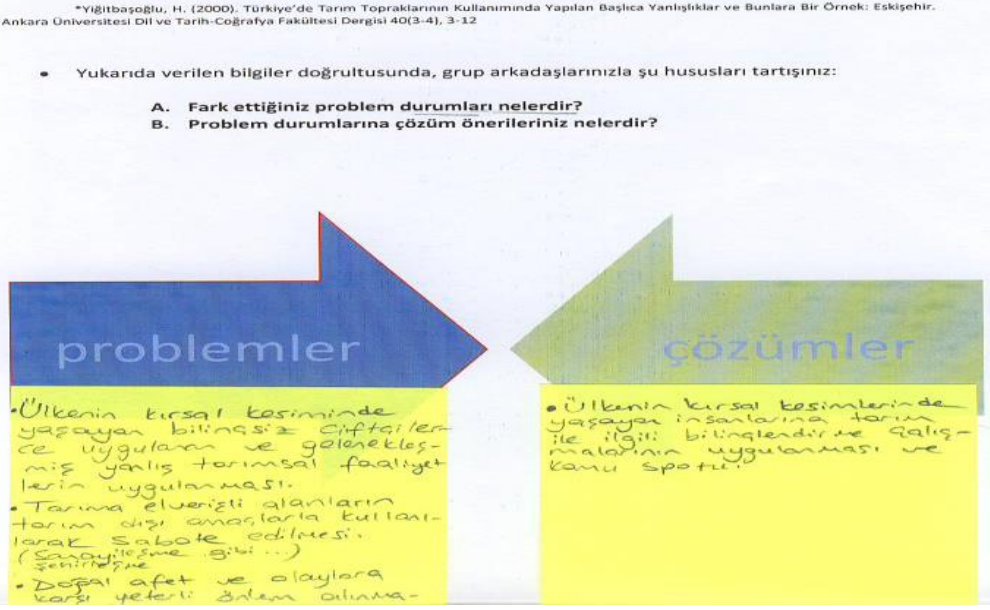
İlke Evin Gencel, Murat Ilıman - Uluslararası Eğitim Programları ve Öğretim Çalışmaları Dergisi, 9(1), 2019, 53-72
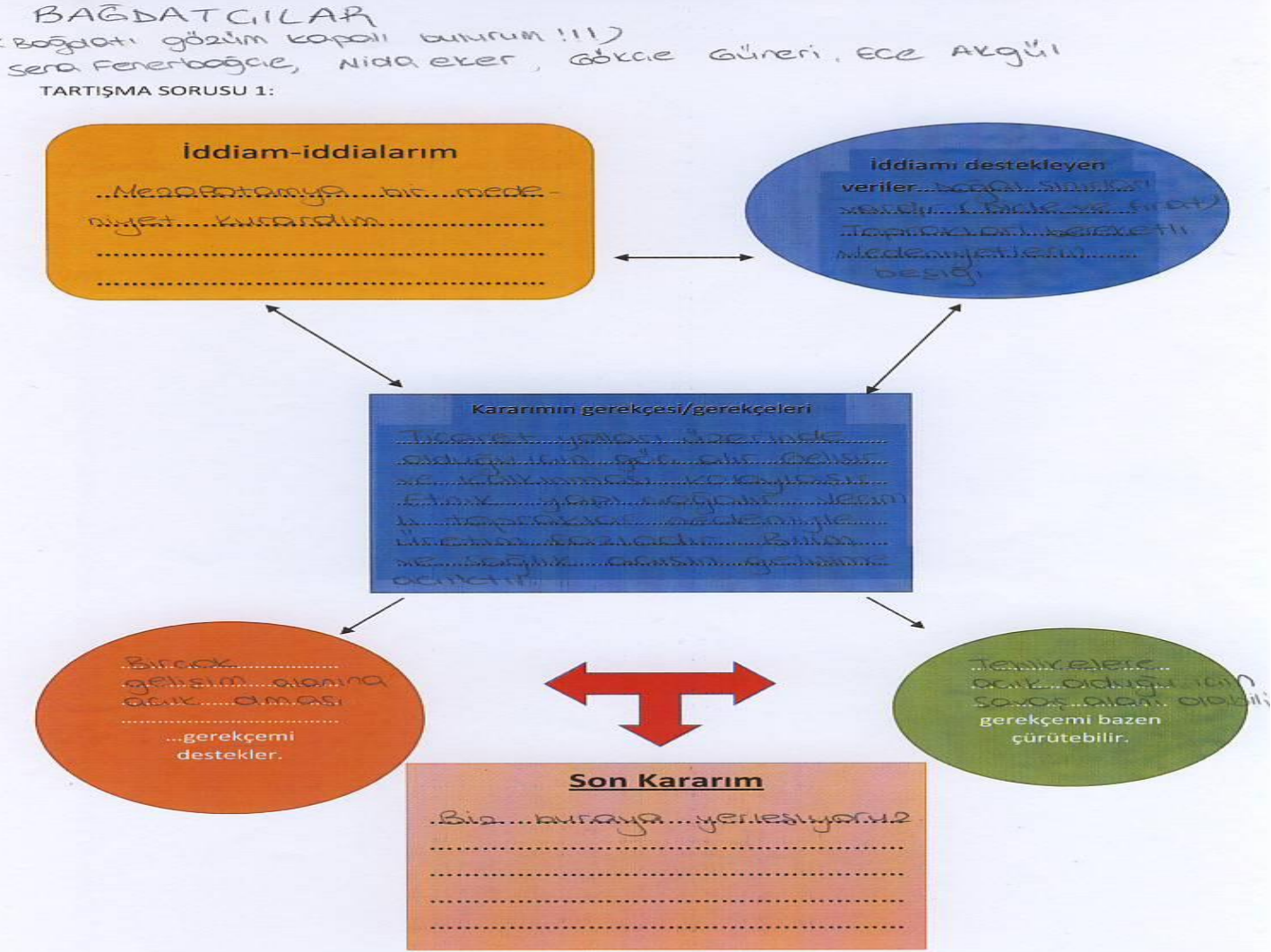

TARTIŞMA SORUSU 2:

\section{Benzerlikler}

Berehetl: Topro hlor umom. ..iklum suthor f fski

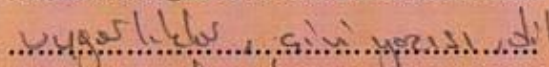
tif nutenatic ustrame.'
Farklar

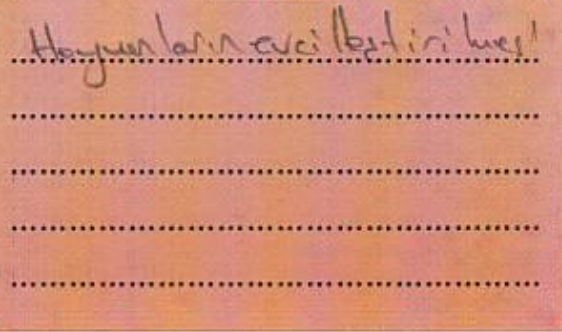

